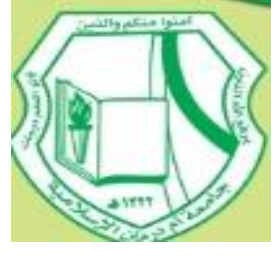

ISSN: 5361-1858

\title{
الفيلم الوثائقي ودوره في الترويج للسياحة في السودان
}

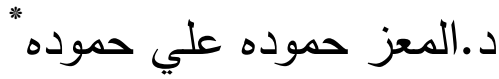

| (أستاذ مساع جامعة بحري - السودان

مستخلص

جاءت هذه الدراسـة لتقف على مدى فاعلية الأفلام الوثائقية في التعريف و الترويج للسياحة في السودان، واتخذت من سلسـة أفلام أرض السمر دراسـة حالة، وهدفت هذه الدراسـة إلى معرفة دور الأفلام الوثائقية في الترويج للسياحة في السودان والوقوف على الدور الذي تقوم به سلسلة أفلام أرض السمر في الترويج للسياحة في السودان، وانطلقت الدراسـة من فرضية أساسية هي: أن الأفلام الوثائقيـة التي تروج للسياحة في السودان لم تخضع للمعايير المهنية والفنية من حيث عملية الإنتاج التلفزيوني، بالإضافة إلى عدد من التساؤلات أهمها: إلى أي مدى ساهمت سلسلة أفلام أرض السمر في الترويج و التعريف بالأماكن و المواقع السياحية في السودان، واستخدت الدراسة المنهج الوصفي، أسلوب دراسة الحالة، واعتمدت الدراسة على عددٍ من الأدوات البحثية وهى: الاستبيان والملاحظة، وتَّم تقسيم الدراسة إلى ثلاثة محاور حيث كان المحور الأول عن الفيلم الوثائقي، بينما المحور الثاني تطرق للسياحة و الإعلام السياحي و جاء المحور الثالث متتاولا إجراءات الدراسة الميدانية، وتوصلَّت هذه الدراسة إلى عدد من النتائج أهمها: أن سلسلة أفلام أرض السمر سـاهمت في الترويج للسياحة في السودان بصورة كبيرة وأن هنالك ضـف في إنتاج الأفلام الوثائقية التي تروج للسياحة في السودان وفقا للمعايير المهنية والفنية، وبناء على النتائج يوصي الباحث بالاتي: إجراء المزيد من البحوث في مجال تطوير صناعة الفيلم الوثائقي في السودان وتتجيع الاستثمار في مجال الإعلام للاخول في إنتاج الأفلام الوثائقية التي تروج للسياحة. 


$$
\text { الفيلم الوثائتي ودوره في التوزيج للسياحة في السودان- د.المعز مهوده علي هموده }
$$

\section{Abstract}

This study explored the extent of documentary films' effectiveness in introducing and promoting tourism in Sudan in which the film series Ard-AISomur was taken as a case study. The basic premise was that documentary films which promoted tourism in Sudan had not been subjected toexistening professional and technical standards in television production process; many questions were presented, however, the most important of which was the extent thatArd-AlSomur series' had contributedto promoting and guiding tourists to sites and tourism landmarks in Sudan. The descriptive and case study approach was used for which a questionnaire and an interview were adopted as data collection tools. The study was divided into three sections: the first tackled the documentary film; the second was on tourism and media; and the third covered the field study's procedures. A number of findings were reached, the most important of which are that: The Ard-alsumor films series have significantly contributed to the promotion of tourism in Sudan and that there are production weaknesses in documentaries that promote tourism in Sudan incompatible with theprofessional and artistic standards. Accordingly, the researcher recommends the conduction of more research to develop the area of documentary film industry in Sudan and to encourage investment in the media by engaging in the production of documentary films that promote tourism. 
مقدمة:

قد أصبحت السياحة الصناعة الأولى في العالم نظراً إلى تصاعد أهميتها عالمياً منذ منتصف القرن العشرين وإلى يومنا هذا. وفي إطار تطور وسائل الإعلام ونموها وانتشارها بشكل ملحوظ فإنه يزداد الاعتماد عليها لتلبية احتباجات مستخدميها. يعد قطاع السياحة أحد القطاعات التي حاولت الاستفادة من وسـائل الإعـلام المختلفة في الترويج

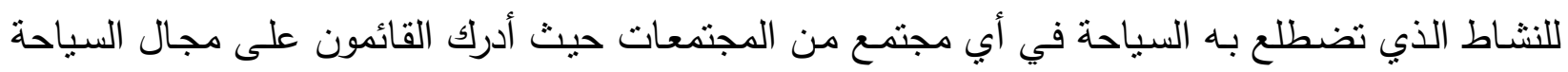

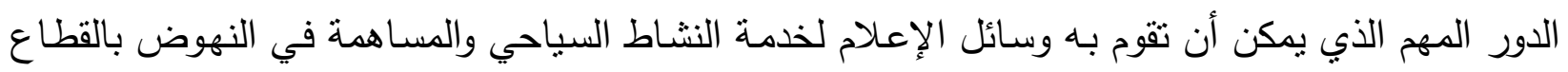

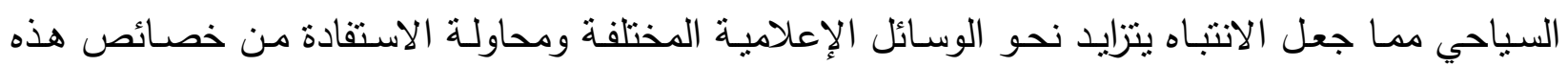
الوسائل في المجال السياحي. وشهدت السنوات الأخيرة طفرة نوعية في صناعة الأفلام الوثائقية واتضـح الدور الذي يمكن أن تؤديه

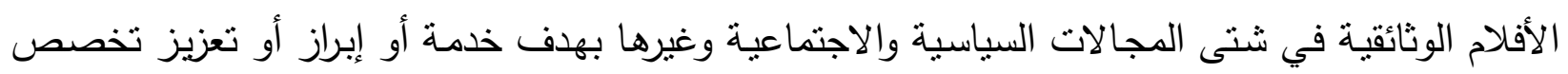

وهذه الدراسة تهتم بدور الفيلم الوثائقي في الترويج للسياحة في السودان وخاصة أن السودان بلد متتوع

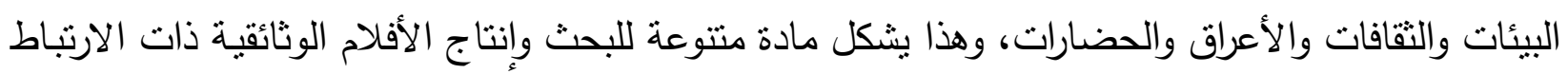
بالسياحة، ومحور هذه الدراسة سلسلة أفلام أرض السمر التي توثق للسياحة في السودان والكثير من المناطق السباحية.

\section{أهمية الدراسة:}

إنّ للسياحة دور مهم في إقامة علاقات طيبة وتحقيق التكيف والتفاهم مـع العالم، والإعلام السباحي يسنطيع أن يؤدي دور مهما في مجال الترويج السياحي للمنجزات وتفسير وشرح الخدمات السياحية للسائحين

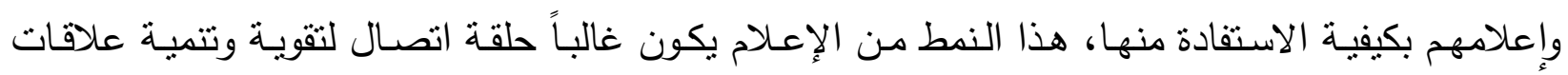
المرتمين والمنتفعين بالسياحة في أي بلد. مشكلة الدراسة:

هناك العديد من المعوقات التي تواجه إنتاج الأفلام الوثائقية في السودان أدت إلى ضعف إنتاج الفيلم الوثائقي مما انعكس سلباً على الترويج للسياحة في السودان وذللك بعدم توظيف إمكانات الفيلم الوثائقي ودوره في إحداث عملية الترويج، وتتضح مشكلة الدراسة بصورة دقيقة من خلال التساؤل الرئيس التالي: إلى أي أي مدى ساهمت أفلام سلسلة أرض السمر في الترويج للسياحة بالسودان؟ 


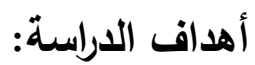

1 1. معرفة كم ونوع الأفلام الوثائقية التي تروج للسياحة في السودان.

2. الوقوف على سلسلة أفلام أرض السمر ودورها في الترويج للسياحة في السودان.

3. التعرف على التحديات التي تواجه إنتاج الأفلام الوثائقية.

فرضيات وتساؤلات الدراسة:

تحنوي هذه الدراسة على فرضية أساسية وتتفرع منها عدة تساؤلات.

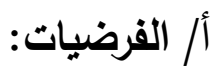

الأفلام الوثائقية التي تروج للسباحة في السودان لم تخضع لثـيء للمعايير المهنية والفنية لعملية الإنتاج

التلفزيوني.

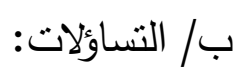

1. إلى أي مدى هناك إنتاج أفلام وثائقية تروج للسياحة في السودان؟

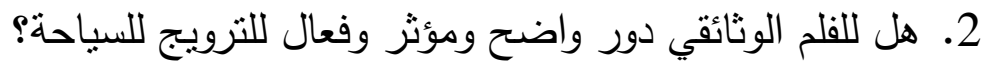

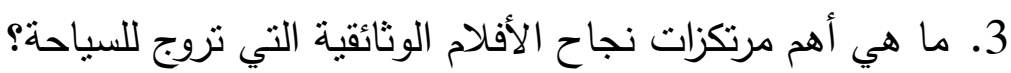

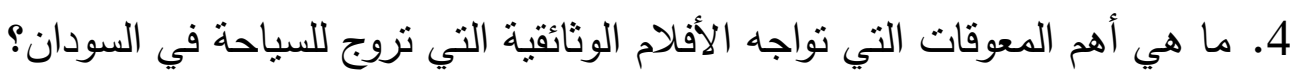

5. إلى أي مدى ساهمت سلسلة أفلام أرض السمر في الترويج للسياحة في السودان؟

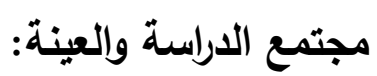

المجتمـع في هذه الدراسـة يثـل خبراء إعلاميين ومتخصصين في صناعة الفيلم الوثائقي وخبراء

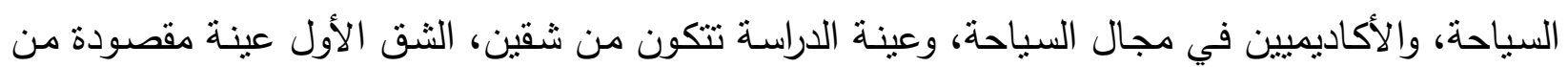

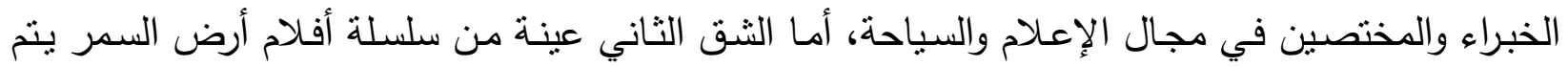

اختيارها بصورة عشوائية منتظمة.

المنهج:

تم استخدام المنهج الوصفي التحليلي بشقيه (الكمي، والنوعي) وتم استخدام أسلوب تحليل المضمون.

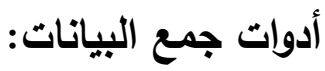

تم استخدام عدة أدوات بحثية وهي الاستبيان والملاحظة وتحليل المضمون.

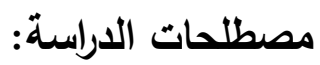

Documentary Film الفيلم الوثائقي

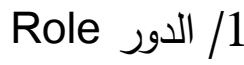

Tourism السياحة السئ 3/ الترويج 
الفيلم الوثائقي:

تعتبر البداية الأولى للفيلم الوثائقي عام 1895م بظهور اختراع لويس لومبيز لجهاز التقاط الصورة

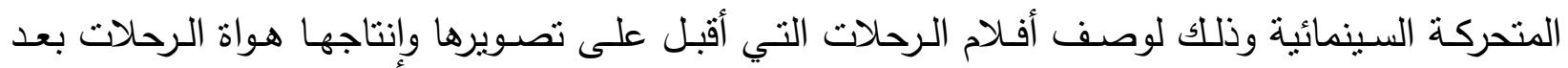
اكتشافه آلة التصوبر بهدف توثيق أوجه نشاطهم وتسجيل مشاهداتهم بالصور المتحركة لإعادة عرضها فيما

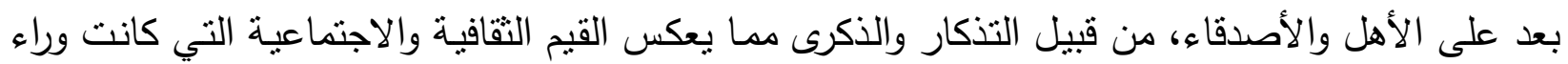

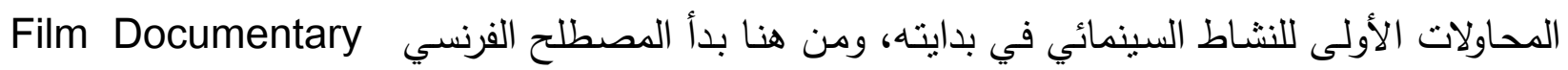

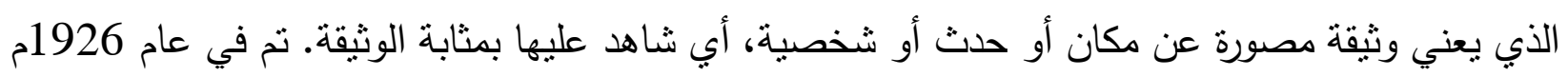

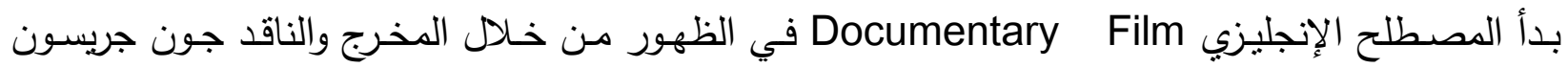
New York sun عندما حدد صفات الفيلم الوثائقي في مقال له نشر في جريدة (John Grierson)

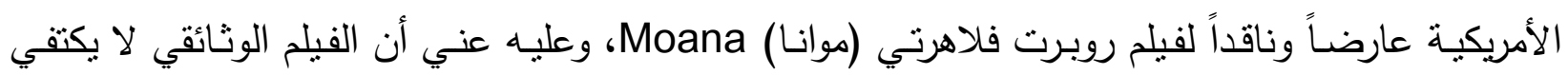

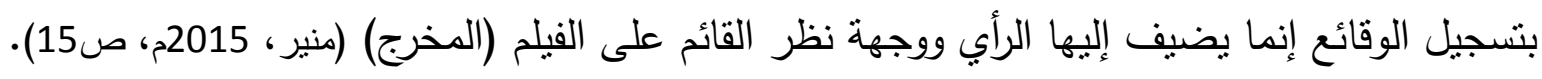
التعريفات المختلفة للفيلم الوثائقي:

إن تباين وجهات النظر حول شكل ومضمون الفيلم التسجيلي الوثائقي انعكست على التعريفات المختلفة للفيلم نفسه مما يعرض علينا تتاولها بشيء من الإيجاز للآراء المتتوعة حوله.

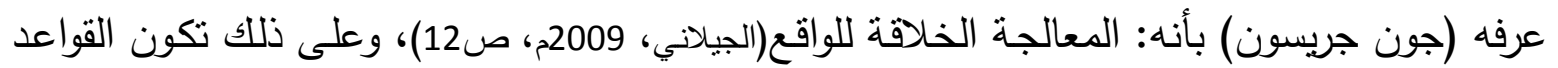
الأساسية للفيلم التسجيلي عند (جريسون) كالآتي:

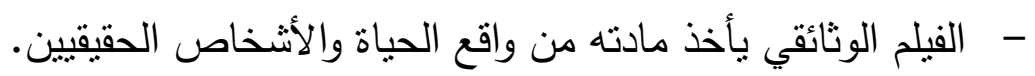

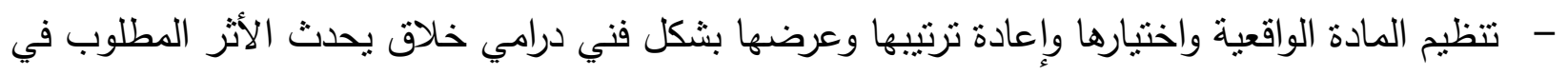

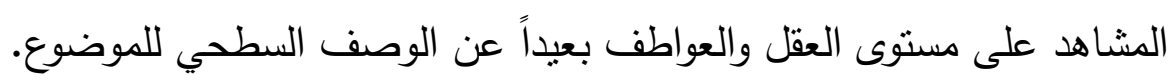

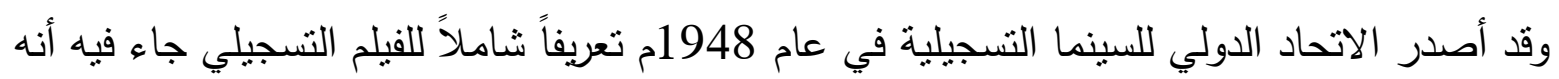

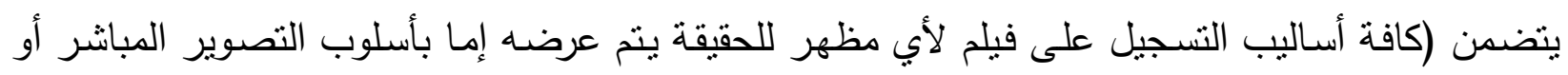

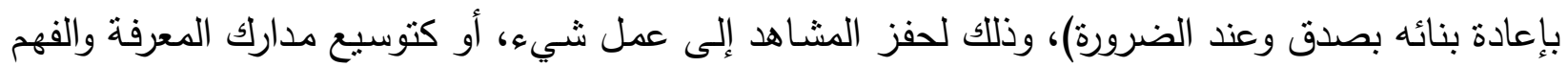

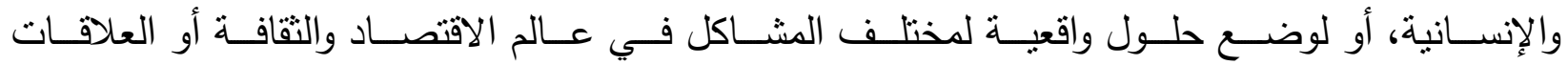
الإنسانية(علي،2015م، ص10).

أمـا التعريف الذي ورد بالموسـوعة البريطانيـة الجديدة للفيلم التسـجيلي فهو : "أنـه نـوع مـن الأفـلام

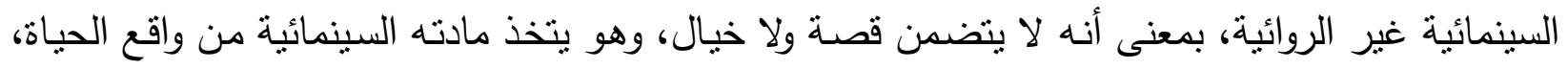


فيصور هذا الواقع ويفسر حقائقه المادية، أو يعيد تكوين هذا الواقع وتعديله بشكل يعبر عن الحقيقة الواقعة

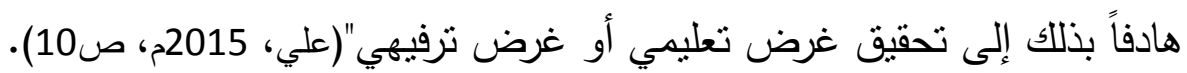
الاتجاهات القنية للفيلم الوثائقي:

الفيلم الوثائقي هو شكل لمشاهدة الأحداث والقصص الواقعية لا لقولها بمعالجات تعتمد في الأساس على الصورة قبل الصوت واللقطة قبل الكلمة والتعبير قبل الوصف بالتركيز دون الإفاضة وهكذا دائماً الفيلم الوثائقي يرتبط ارتباط جدلياً بالتعبير المرئي حيث يعتمد السيناريو فيه على التعبير الصوري وذلك من خلال

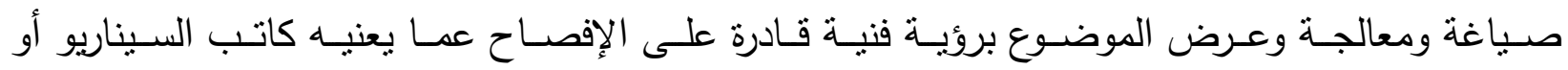
المخرج(الجيلاني، 2009م، ص19)، ولعلة من الجدير هنا أن نذكر ما قاله الباحث محمد القرافي (إن اللغات تقيم

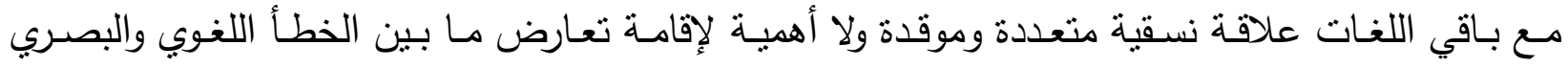
بوصفهما قطبين كبيرين ويحظى كل منهما بالتجانس والتماسك في غياب أي رباط بينهما، وأن العالم المرئي

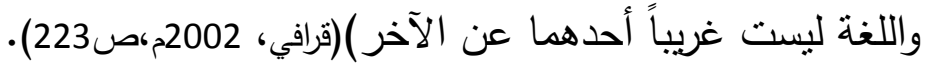

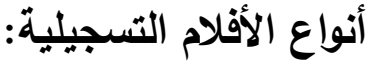

حصر (سبوتزوود) في كتابه الفيلم وأصوله الفنية أنواع الأفلام التسجيلية المنتجة سينمائياً أو تلفزيونياً فيما يلي:

1/ الفيلم التسجيلي التقليدي Classical Documentary Film: وهو الفيلم الذي تفوق فيه الملاحظة الثرح. وهو أنقى أنواع الأفلام التسجيلية، وقد وصل هذا النوع من الأفلام التسجيلية إلى أعلى مستوياته في إنجلترا.

\section{2/ الفيلم الموسيقي التسجيلي Lyrical Documentary Film:}

وفي هذا النوع يتعدد صناع الأفلام الاستغناء عن الحوار لأسباب فنية أو لتفادي القيود الرقابية أو

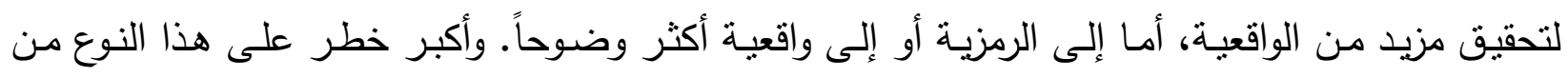

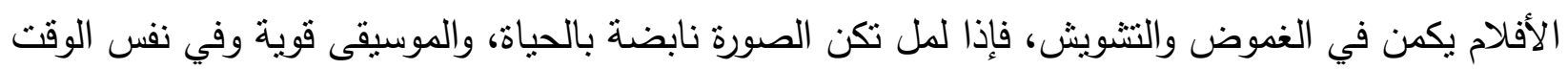
مرنـة وسهلة، والصوت فنياً، فلن نحصل إلا على نماذج سيئة، هذا بالإضـافة إلى أهمية الخبرة والأرضية المشتركة بين صانع الفيلم والجمهور المستهدف منعاً للفهم الخاطئ للرسالة. 3/ الفيلم المقالي Editorial Film:

وهو مجرد شرائط من الفيلم الخام ملأها المنتج بأفكاره وتصوراته الخاصة، وأبرز عيوب هذا النوع من

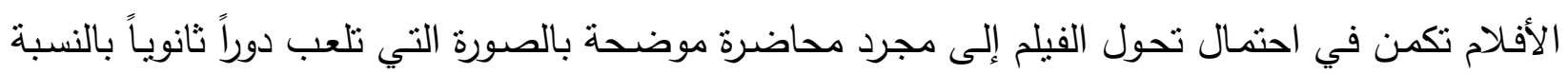
للتعليق الصوتي، وكثير من الأفلام التعليمية هي أفلام تحريرية، الغرض الأساسي منها هو هرض عرض الحرف الحقائق. 
4/ الفيلم الجدلي The Argumentative Film: وهو الذي يركز على تصوير الحقائق وتصبح الثاشة أداة فعالة في اجتذاب اهتمام المتفرج وإمتاعه في الوقت ذاته بموضوع ما. وتحقق الأنواع السابقة نوعاً من الصلة بواقع الحياة أو بعبارة أخرى تقتح نافذة على العالم من خلال مفردات لغة السينما. 5/ أفلام الرسوم المتحركة Cartoon \& Animated Film: تمثل أفلام الرسوم المتحركة مكاناً مههاً إذا ما حاولنا قياسها بالمقاييس نفسها التي تقيس بها غيرها من

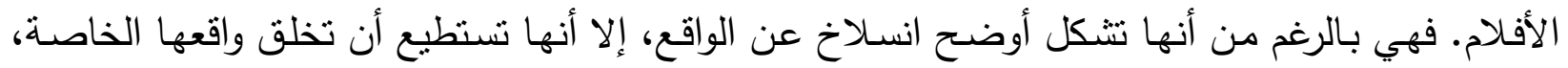

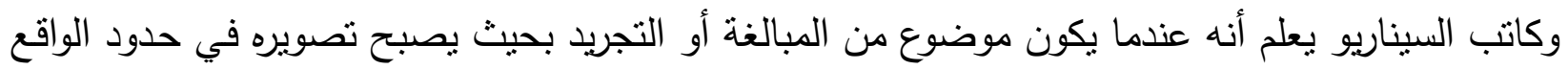

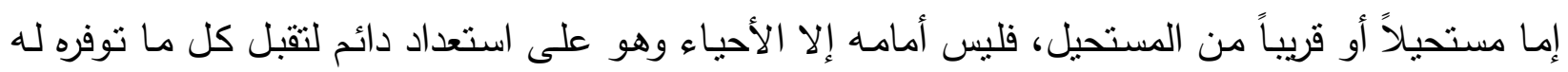
صناعة السينما من إمكانيات.

6/ أفلام الطليعة The Avantgard Film: هي كل جديد في عالم الأفلام (الحديدي وعلي، 2004م ، ص 18):

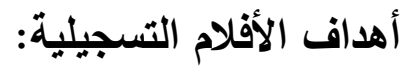
يمكن استخدام الفيلم التسجيلي بنجاح كبير لتحقيق أهداف مختلفة في عدة مجالات: أ. التوثيق والتسجيل التاريخي. ب. عرض القضايا والمشكلات المجتمعية. ج. المساهمة في المجال التعليمي والإرشادي والتوعية. د. المساهمة في خدمة القضايا السياسية وعرضها على على الرأي العادي العام العالمي.

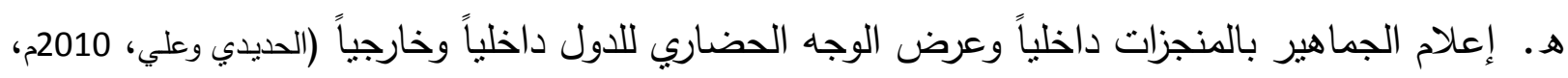
ص69).

المذاهب السينمائية في تقديم الأفلام التسجيلية: لكي تقدم عملاً متقناً ذو هوية واضحة ستجد نفسك في هذا العمل تتحو منحى أحد المذاهب السينمائية التالية وقد تجمع أو تعدل حسب ما يتطلبه الموضوع. 1/ الطريقة التفسيرية:

في هذا النوع يتم طرح القضايا بشكل مباشر عبر شرح العلاقة بين السبب والنتيجة أو تلخيص قضية

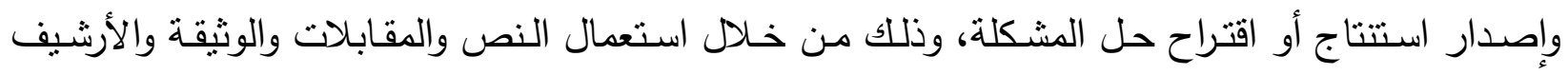
والرسوم التوضيحية التي تمهد لمناقتشة تاريخية. 


\section{2/ طريقة الملاحظة (السينما المباشرة):}

وهنـا يـتم تسـجيل الأحـداث والتجـارب الإنسـانية المعانــة عبر مشـاركة الكـاميرا للمواقف الحميمـة والثخصـية، وتعتمــ هذه الطريقـة على التصـوير الخـاص والصـوت المباثـر وفي الأسـاس فـإن التعليق والموسيقى الخارجية والعناوين المكتوبة وإعادة التمثيل وحتى المقابلات جميعها غير مقبولة هنا. 3/ الطريقة التفاعلية:

هي طريقة تبين تفاعل صانع الفيلم مع الموضوع، حيث تسمع صوته ينخرط في حوارات مع شهود عيان، أو قد يكون هو نفسه شاهد عيان أو محقق. وقد يستخدم أساليب فنية مختلفة كاستخدام شاشة الكاميرا

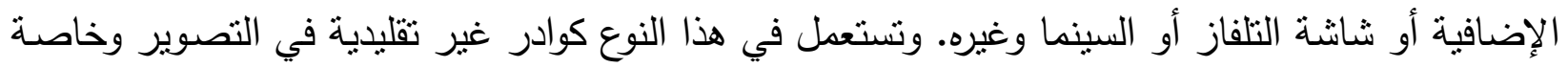

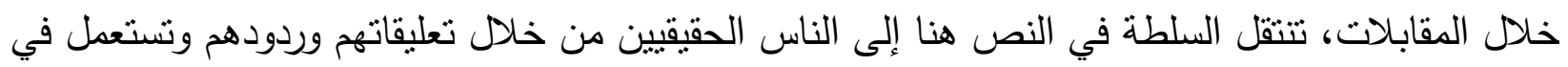
هذا النوع التصريحات المتناقضة حول نفس الموضوع لحث المشاهد على إعادة تقييم موقفه.(نصار، 2015م،

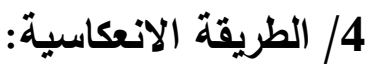

هنا تظهر الروئية الذاتية لصانع الفيلم والتي يشكل من خلالها حول القدرة على تفسير المعالم وتقديم

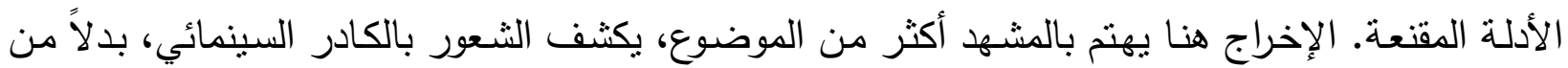

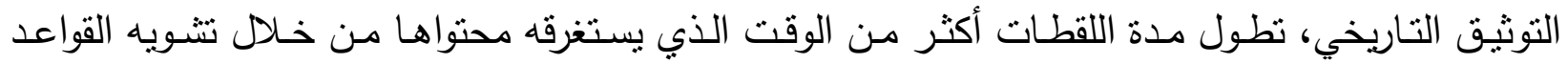
السينمائية تعمل التتاقضات غير المتوقعة إلى تحويل الغريب إلى عادي وتحويل العادي إلى غريب.

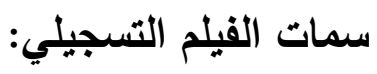

الفيلم التسجيلي هو شكل مميز من الإنتاج السينمائي يتميز بما يلي:

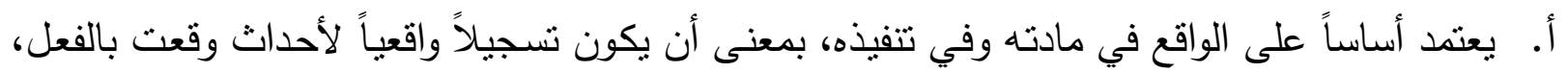

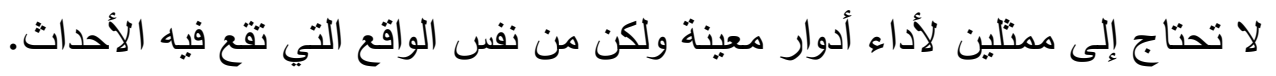

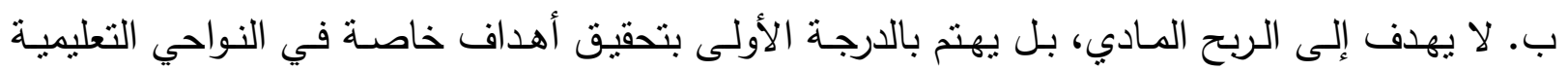

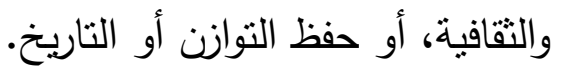

ج. يختلف عن الفيلم الروائي من حيث هدفه المادي، فالأفلام التسجيلية غالباً ما تتتجها الدول لمعرفتها

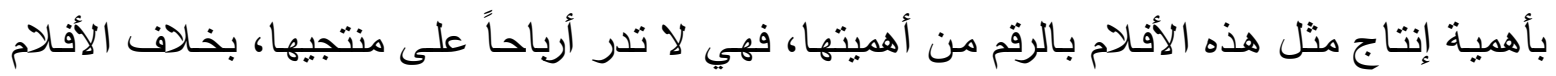

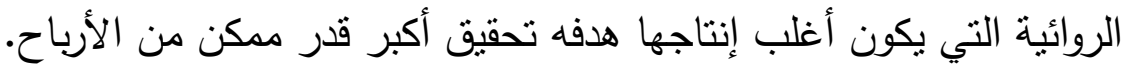

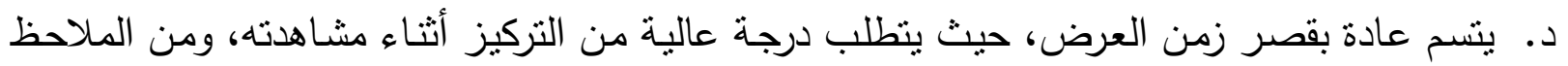
دائماً أن يكون إنتاج الأفلام التسجيلية لا يزيد في أغلبه عن 20 -30 - 45 دقيقة على أكنة أكثر تقدير 
وذلك نظراً لأن إنتاج منت هذه الأفلام يكون موجهة إلى نوعية معينة من الجماهير، يحمل لها الأهداف

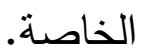
هـ يخاطب في العادة فئة أو مجموعة مستهدفة من الجماهير، وأثناء الإعداد لإنتاج فيلم من الأفلام التسجيلية يُحدد الجمهور المستهف لهذا الفيلم وعلى أساس خصائصهم يكون أسلوب المعالجة ونوعية المعلومات، وكيفية تتاولها وتقديمها.

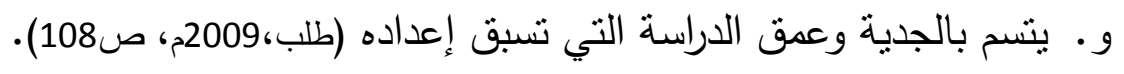
من خلال هذا السرد نجد أن الفيلم الوثائقي يقوم بدور فعال ومؤثر في عرض وجه السودان في الخارج

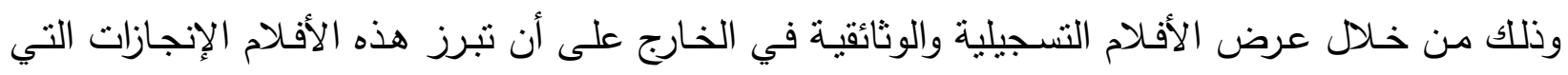
يحققها السودان في مختلف المجالات وذللك عن طريق القنوات التلفزيونية أو المعارض الدولية أو من خلال لال السفارات والمكاتب الإعلامية السودانية بالخارج. وبذلك يستطيع الفيلم الوثائقي أن يؤدي دوراه في تكوين الصورة الذهنية الجيدة عن السودان في الخارج؛

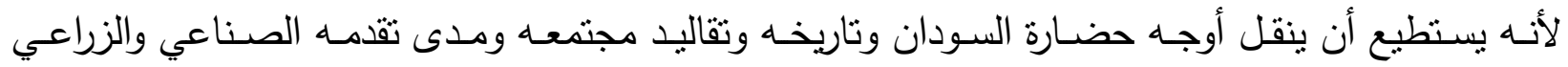

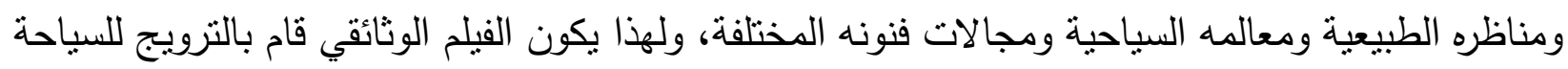

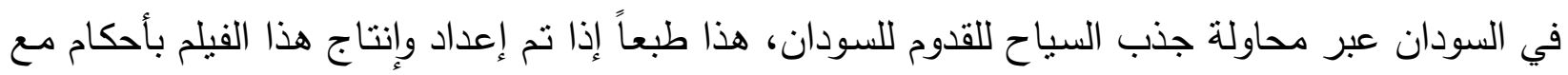
إيقاع المعايير المهنية والفنية لإنتاج الأفلام الوثائقية.

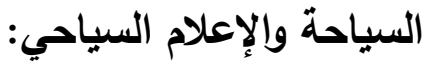
يعبر عن السياحة بأنها ظاهرة من ظواهر عصرنا الحالي تتبثق من الحاجة المنزايدة للراحة، وإلى تغيير الهواء والإحساس بجمال الطبيعة والثتعور بالبهجة والمتعة بالإقامة في مناطق لها طبيعتها الخاصـة، ويعد هذا التعريف من أقدم التعريفات التي وضعت للسياحة وهو التعريف الذي وضعه الألماني جوبير فرديلير عام 1905م(سلمان ، 2016م ، ص 15).

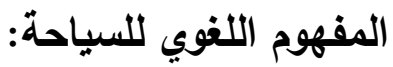

إذا بدأنا بتعريف المفهوم اللغوي للفظ السياحة فتتجد إنه يعني التجول وعبارة ساح في الأرض تعني

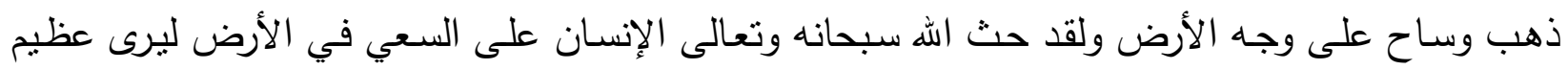

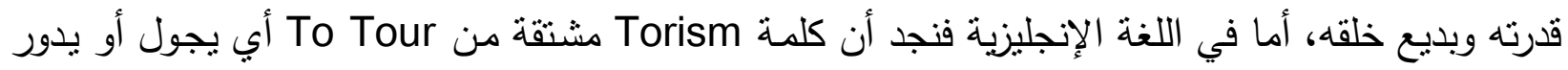

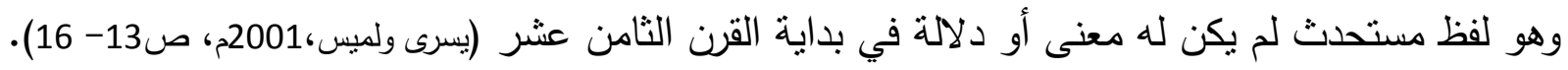
وهي عبارة عن انتقال الإنسان من مكان إلى مكان ومن زمان إلى زمان (السياحة العالمية) أو الانتقال في البلد (السياحة الداخلية) لمدة يجب أن ألا تقل عن 24 سـاعة حيث تكون من أجلى الإقامـة الدائمـة، 
وأغراضها تكون من أجل الثقافة والأعمال أو الدين أو الرياضة أو هي حركة الأفراد والجماعات من أماكن

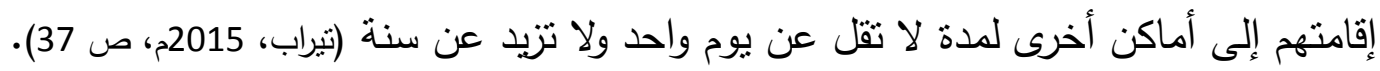
كما أن السياحة في ضوء القاموس الدولي السياحي "مونت كارلو 1961م تعبر عن أسفار المتعة التي تتمثل في مجموعة الأنشطة البشرية التي تعمل على تحقيق هذا النوع من الأسفار والصناعة التي تتعاون على إثباع رغبات السائح، ونلمس أن هذا التعريف قد قصر الأنشطة السباحية على عملية المتعة أيا كان

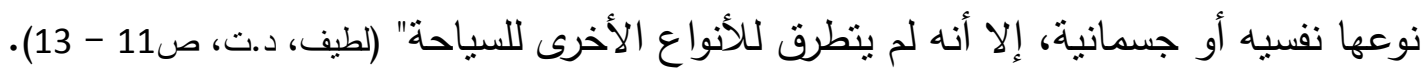

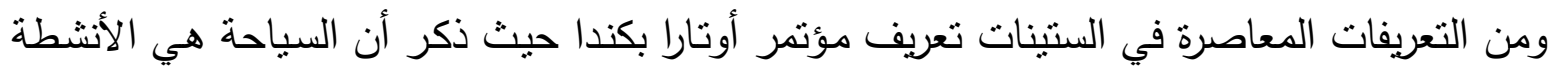
التي يقوم بها الثخص إلى مكان خارج بيئته المعتادة لمدة زمنية دون أن يكون غرضـه من السفر داخل فئل

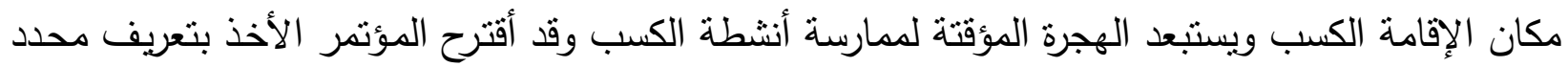
للسائح والسائح هو الذي يسافر لبلد غير الذي يقيم فيه بشكل معتاد ولمدة لا تقل عن ليلة واحدة ولا نزيد عن

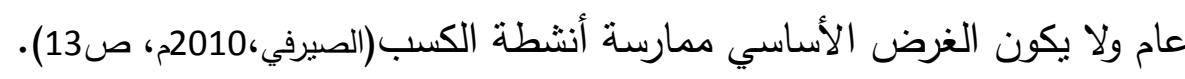
أنواع السياحة: يمكن تقسيم أنواع السياحة وفقاً لعدد من الاعتبارات والأسس منها:

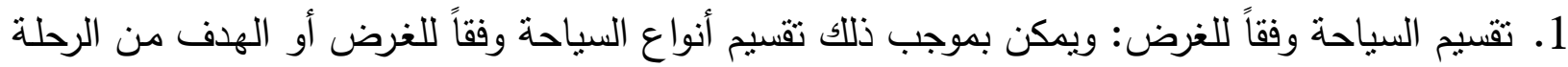
السياحية فمنها (قضاء الإجازات والتزفيه والرياضة وزيارة الأماكن الأثرية، زيارة الأماكن المقدسة). 2. تقسيم السياحة وفقاً للعدد مثل: (السياحة الفردية، السياحة الجماعية.. الخ). 3. السياحة وفقاً للعمر : (سياحة الطلائع، سياحة الثباب، سياحة الناضجين، سياحة المتقاعدين).

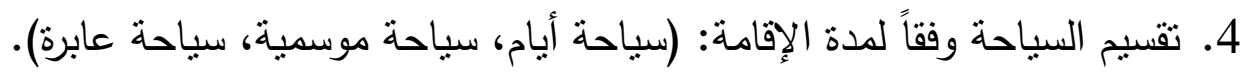

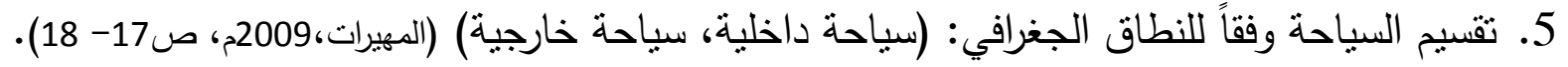

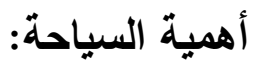
تتبع أهمية السياحة كونها القطاع الذي يزيد من إيرادات الدولة وذلك لما يلي: 1. أن السياحة تمثل ظاهرة الانتقال المؤقتة التي يقوم بها عدد كبير من الناس فيتركون مكان إقامتهر

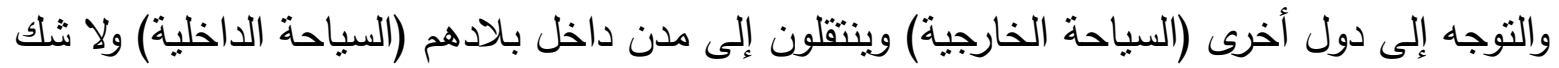
أن المدة التي بستغرقها هذا الانتقال تختلف بحسب رغبة السبائح وتتوقف على مقدرة السائح المالية على الإنفاق في الخارج مدة طويلـة أو قصبرة وقوانين النقد في البلد التي يخرج منها ومدى تأثنير المتغيرات السياحية في البلد الذي يزوره ومدى رخص تكاليف المعيثة. 
2. السائح في البلا السياحي يقوم بوظيفة استهلاكية ينتج عنها زيادة في دخل البلد وتحدث هذه الزيارة عن

$$
\text { طريق الانتفاع بالخدمات (إقامة، طعام، شراب) (عبدي، 2016م، ص23 - 24 24). }
$$

الإعلام السياحي: - إن

هو التعريف بما يحتويه البلد من معالم سياحية سواء أكانت طبيعية أم أثريـة أم فندقية أو أي مظهر

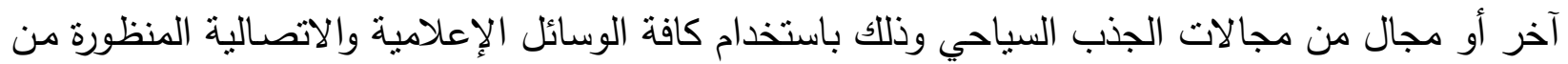

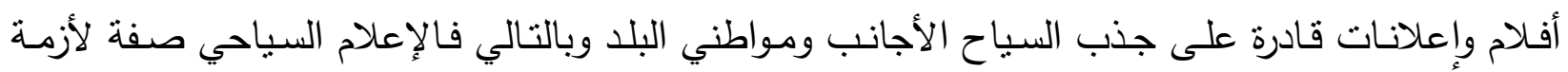
ومحورية الصناعة السياحية.

وعرف محمد منير حجاب الإعلام السياحي بأنه: هو أحد أنشكال الإعلام المتخصص ويمكننا تعريفه بأنه كافة أوجه النشاطات الاتصالية المخططة والمستمرة التي يمارسها إعلاميون متخصصون بهون بهدف تزويد الجمهوريـة بكافة الأخبار والحقائق الصحيحة والمعلومات السليمة عن القضايا والموضوعات والمشكلات ومجريات الأمور المتعلقة بالسياحة بطريقة موضوعية وبدون تحريف عن طريق وسائل وأثكال الاتصال

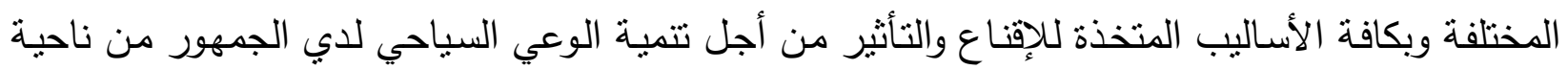

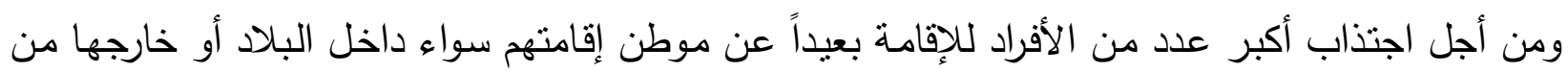

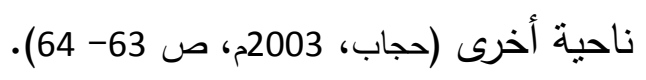

ومن خلال هذا المفهوم الثشامل للإعلام السياحي يلاحظ ما يأتي:

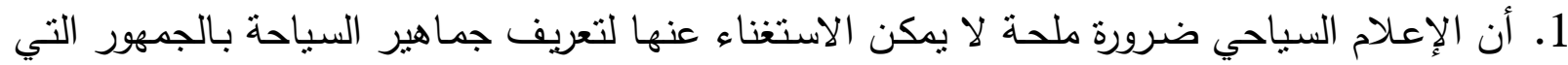
تبذل في هذا الميدان الحيوي وترغيبهم بالزيارات المتكررة. 2. أن الإعلام السياحي نشاط اتصالي له سماته وخصائصسه ووسائله ويستخدم كافة الوظائف كالأخبار والتفسير والإقنـاع والتسـلية، الـخ، في إطـار السياسـة الإعلاميـة والسياحية القوميـة للمجتــع لتحقيق أهدافه. 3. يتسـم الإعـلام السـياحي بالصـدق والدقـة والصـراحة وعـرض الحقائق الثابتـة كـالمنجزات والخـدمات والتسهيلات وبدون تحريف وبأسلوب يستهدف الثرح والتبسيط والتوضيح للحقائق.

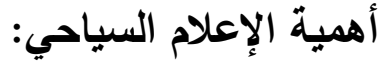
يمكن أن تبرز أهمية الإعلام السياحي فيما يلي:

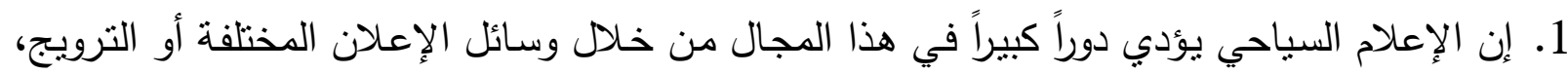
المتمنلة في الوسائل المقروءة والمسموعة والمرئية. 
2. بقدر ما للإعلام السياحي من أثر إيجابي في الترويج السياحي بقدر ما هناك حاجة ملحة لدوره الفعال

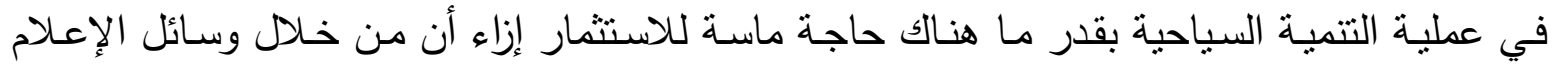
المختلفة يستقى الفرد معلوماته والتي تصله عادة في شكل إخباري عن حقائق ومعلومات سباحية يهتم بها السائح وتدفع شركات السياحة مقابل مادي عن هذه الأخبار ذات الطابع الإعلاني. 3. تنجح الحملة الإعلانية وترتكز على مقدار الثقة أو القرب أو التخصص لهده لوسيلة الإعلام لدي السائح واهتماماتها بالنشاط السياحي وينظر السائح إلى المعلومات والأخبار المنشورة في شكل إعلام إخباري على أنها حقائق كاملة (الصرف ولبس إعلاناً مدفوع الأجر خاصـة وأن الإعلام السياحي لا تنتحكم

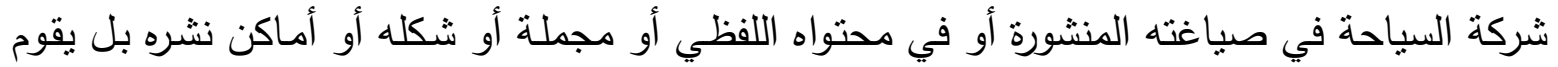

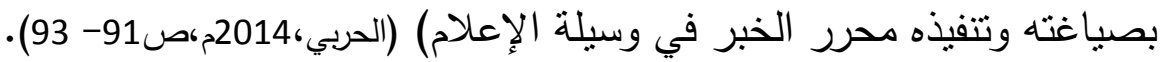

$$
\begin{aligned}
& \text { وهناك محاور مختلفة لأهمية الإعلام السياحي على النحو التالي: } \\
& \text { أولاً: نشر المعرفة السياحة: }
\end{aligned}
$$

يعد الإعـام السياحي أحد الوسـائل العامـة لنشر المعرفـة والثقافيـة السياحية لـدي الجمهور الداخلي والخارجي من خلال المعلومات التي تتشر عن الآثار والمعالم السياحية والخذمات والبرامج المختلفة. ثانياً: تحقيق التوعية السياحية:

يعمل الإعلام السياحي على التوعية والتتسيق الجماهيري داخلياً عن طريق إتباع الأساليب والوسائل

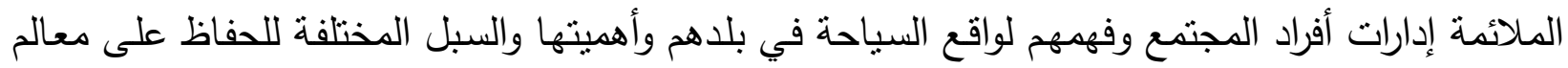
السياحة والآثار الموجودة في البلا.

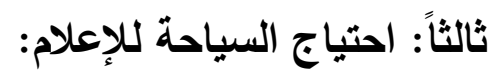
لابد من تخطيط دقيق لبرنامج إعلامي قومي ومحكم تراعي فيه كافة الاعتبارات الإعلامية وتستخدم من خلال كافة الأنشطة الاتصالية والأسـاليب الإقناعية عن طريق جهاز إعلامي يقوم على أسس علدية سـليمة وترعـاه قيـادة عالمـة بمنطلبـات الإعـلام والدعايـة والسياحة المحليـة القوميـة والعالميـة (الجـلاد، د.ت، ص102-102)

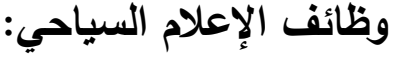

يعدّ الارتفاع بمعدل الجذب السياحي للبلاد من أهم وظائف الإعلام والاتصـال السياحي ويعد الإعلام في المجال السياحي ناجحاً إذا نجح في تعظيم الناتج الاقتصادي والاجتماعي من كافة الأنشطة السياحية وذلك عن طريق العمل على مختلف المحاور وفي إطار من التخطيط، والتتسيق وهذه المحاور هي التي يرتكز عليها الإعلام السياحي ويهذف إليها وتتمنل في: 
1. زيادة أعداد السائحين عن طريق وسائل الجذب السياحي المتتوعة والمتوفرة والمعروفة لدي الجهات

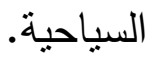

2. زيادة منتسط عدد الليالي السياحية أي منوسط مدة الإقامة وذلك بإبراز المميزات التي يتمتع بها المكان والخدمات الفندقية وغير الفندقية المقدمة للسائح والتركيز عليها والاهتمام بها.

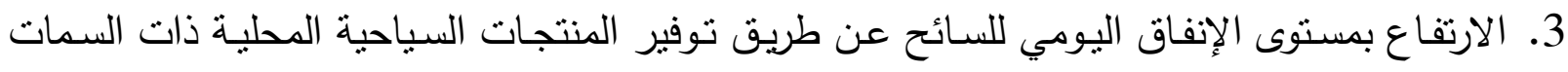
الخاصة والمطلوبة والخدمات السياحية جيدة المستوى. 4. الاهتمام بفتح أسواق جديدة وإقامة معارض دورية لاكتساب العملاء الجدد والمرتقبين. 5. حيث جمهور السياح على معاودة الزيارة وتحفيز الجمهور المرتقب على اتخاذ القرار بالزيادة.

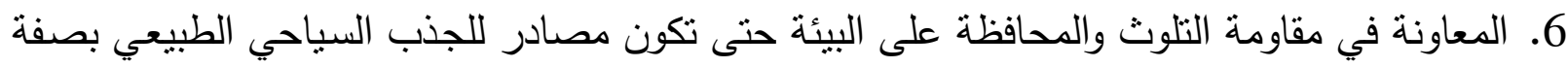
دائمة. 7. الزيادة المستمرة في استخدام مقومات الجذب السياحي المتاحة.

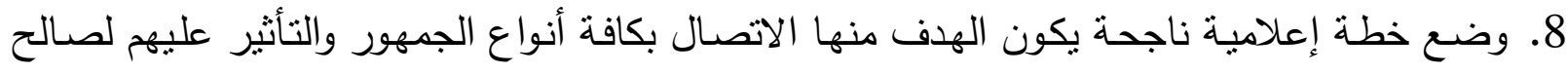
السياحة في البلاد وبما يفيد التوفيق بين مصالح الجمهور ومصالح السياحة بما يحقق الفائدة. 9. نشر الوعي السياحي والتأكيد على أهمية المناطق السياحية والأثرية والمحافظة عليها. 10. إلغاء الضوء على المنتج السياحي بتميزه وإغرائه وتوسع قاعدته بما يجذب الفئات المختلفة (البكري،

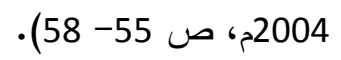
خصائص الإعلام السياحي: 1. التعريف بالمواقع والمراكز والاستثمارات السياحية والترفيهية وغيرها. 2. يعبر عن الحضارات القديمة ونهضتها الحديثة. 3. تقديم المغريات السياحية من فنادق وتسهيلات وغيرها. 4. التعريف بالتسهيلات السياحية التي تقدم للسياح ليتمتع بها عند قدومهاه من إقامة وغيرها. المشاكل التي يعاني منها الإعلام السياحي: بالئ 1. عدم الاهتمام بالمعارض والمهرجانات والإعلانات التي تنؤدي دور في تتجيع السياحة عبر انتشارها عالمياً. 2. عدم التزويج السياحي وتوفير دليل سياحي يتواصل مع السياح ويعرفهم على مناطق البلد. 3. ضعف وسائل الإعلام وعدم مواكبتها للتقنيات العالمية المرئية والمسموعة. 4. عدم وجود برامج سياحية تعرض آثار ومناظر المناطق المراد تحقيق السياحة فيها. 
5. عدم وجود دعاية مضادة تتصدى وتفند مزاعم بعض الدول التي تسعى لتشويه الصورة الحضارية للبلد

$$
\text { على المستوى الاجتماعي والديني والسياحي. }
$$

6. قد تكون الحروب والكوارث المنتــرة عبر وسـائل الإعـلام هي مـانع يحول دون تحقبق الإعـلام

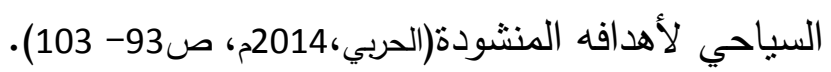

ومن الملاحظة من عرض خصائص ووظائف الإعلام السياحي يمكننا القول إن الإعلام السياحي هو

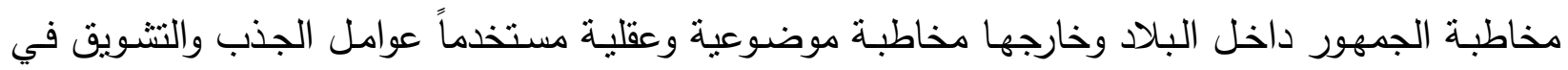
تقديم المنتج السياحي بقصد إقناع الجمهور وإثارة اهتمامه بأهمية السياحة وفوائدها وتتبهيعه على على التعرف على المغريات السياحية والمنتج السياحي. التحليل الإحصائي وإختبار الفرضيات: أولاً: مجتمع الدراسة: يقصد بمجتمع الدراسة المجموعة الكلية من العناصر التي يسعى الباحث أن يعمح عليها النتائج ذات العلاقة بالمشكلة المدروسة. يتكون مجتمع الدراسة من(موظفي التلفزيون القومي كنموذج) حيث قام الباحث بتوزيع عدد (23) استبانة على المستهدفين. وللخروج بنتائج دقيقة قدر الإمكان حرص الباحث على تتوع عينة الدراسـة من حيث شملها على

فيما يلي وصفاً لأفراد الدراسة وفقاً للمتغيرات أعلاه خصائص (المبحوثين) 1 يوضح الجدول رقم (1) التوزيع التكراري لأفراد عينة الدراسة وفق النوع

\begin{tabular}{|c|c|c|}
\hline النسبة المئوية & التكرارات & النوع \\
\hline 26.1 & 6 & ذكر \\
\hline 73.9 & 17 & أنتي \\
\hline 100 & 23 & المجموع \\
\hline
\end{tabular}

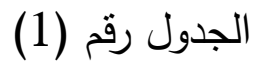


يتضح من الجدول رقم (1) أن أفراد الدراسة في متغير النوع، الذكور بلغ عددهم (6) وبنسبة (26.1\%) ونجد الإناث بلغ عددهن (17) وبنسبة (73.9\%).

2-الوظيفة: 2 يوضح الجدول رقم (2) والثكل (2) رقما لتوزيع التكراري لأفراد عينة الدراسة وفق الوظيفة الجدول رقم (2)

\begin{tabular}{|c|c|c|}
\hline النسبة المئوية & التكرارات & الوظيفة \\
\hline 13.0 & 3 & منتج \\
\hline 13.0 & 3 & معد \\
\hline 34.8 & 8 & مخرج \\
\hline 4.3 & 1 & مصدر \\
\hline 8.7 & 2 & أكاديمي \\
\hline 26.1 & 6 & أخري \\
\hline 100 & 23 & المجموع \\
\hline
\end{tabular}

يتضح من الجدول رقم (2) أن أفراد الدراسة في متغير الوظيفة، منتج بلغ عددهم (3) وبنسبة (13\%) ونجد

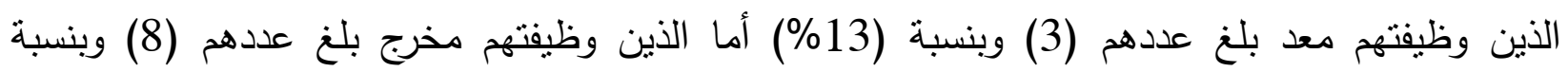
(34.8\%) ونجد الذين وظيفتهم مصدر بلغ عددهم (1) وبنسبة (4.3\%) ونجد الذين وظيفتهم أكاديمي بلغ

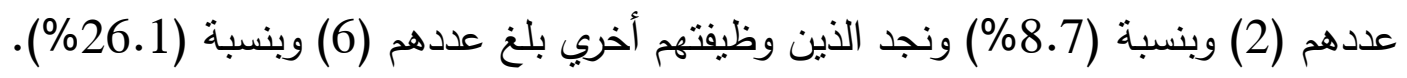
3- سنوات الخبرة: يوضح الجدول رقم (3) التوزيع التكراري لأفراد عينة الدراسة وفق سنوات الخبرة

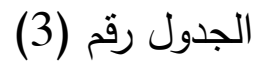

\begin{tabular}{|c|c|c|}
\hline النسبة المئوية & التكرارات & المدة \\
\hline 4.3 & 1 & أقل من5 سنوات \\
\hline 8.7 & 2 & 2-10 سنوات \\
\hline 26.1 & 6 & 11-15 سنة \\
\hline 60.9 & 14 & 15 فأكثر \\
\hline 100 & 23 & المجموع \\
\hline
\end{tabular}


يتضح من الجدول رقم (3) أن أفراد الدراسة وفق سنوات الخبرة،أقل من5 سنوات بلغ عددهم (1) وبنسبة

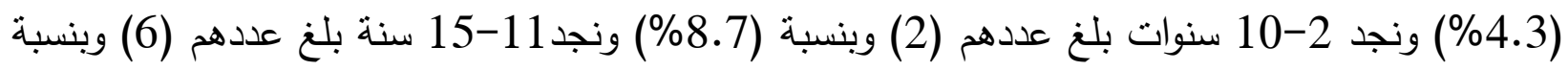
(26.1\%) ونجد الذين بلغت سنوات خبرتهم أكثر من 15 سنة (14) وبنسبة (60.9\%ة (24).

ثانياً: وصف الاستبانة:

احتوت الاستبانة على أقسام رئيسية - القسم الأول: تضمن البيانات الثخصية لأفراد الدراسة، حيث يحتوي هذا الجزء على بيانات حول

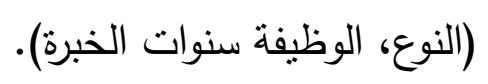

- القسم الثاني: البيانات المتعلقة بالدراسة يحتوي هذا القسم على عدد محاور الاستيان ويتكون من عدد 5 محاور طُلب من أفراد الدراسة أن يحددوا استجابتهم عما تصفه كل عبارة.

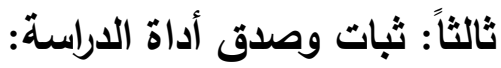
الثبات والصدق الإحصائي: التان

يقصد بثبات الاختبار أن يعطي المقياس نفس النتائج إذا ما استخدم أكثر من مرة واحدة تحت ظروف ممانلة

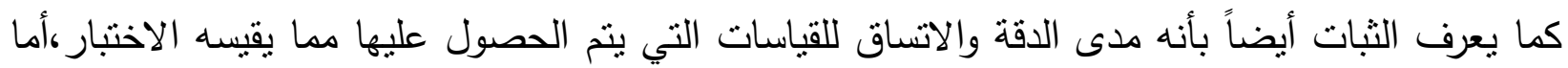

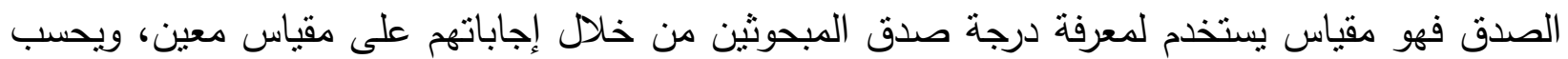

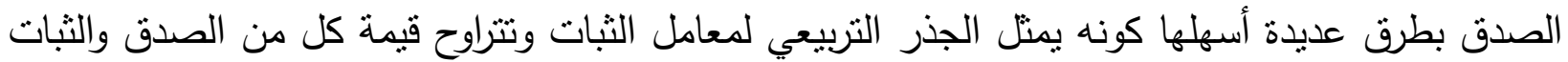
بين الصفر والواحد الصحيح. وقام الباحث بحساب معامل ثبات المقياس المستخدم في الاستبانة عن طريق معادلة ألفا-كرونباخ، وكانت

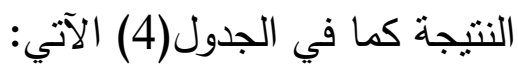
الثبات والصدق الإحصائي لإجابات أفراد العينة على الاستبيان لعدد (5) محاور.

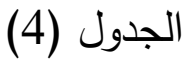

\begin{tabular}{|c|c|c|c|}
\hline الصدق & الثبات & عدد العبارات & المحور \\
\hline 0.926 & 0.858 & 21 & الاستبانة \\
\hline
\end{tabular}

يتضح من نتائج الجدول أعلاه أن معاملي الثبات والصدق لإجابات أفراد الدراسة على العبارات

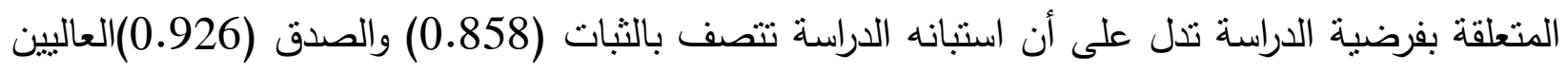
بما يحقق أغراض الدراسة، ويجعل التحليل الإحصائي سليماً ومقبولاً الإلئ

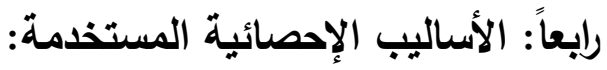
لتحقيق أهداف الدراسة وللنحقق من فرضياتها، تم استخدام الأساليب الإحصائية الآتية: 


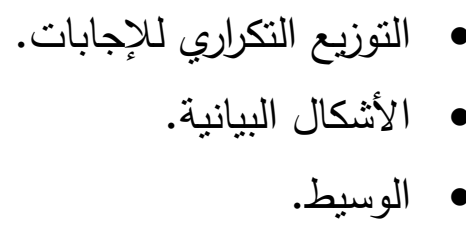

اختبار مربع كأي لدلالة الفروق بين الإجابات.

معامل الفاكرونباخ.

للحصول على نتائج دقيقة قدر الإمكان، نم استخدام البرنامج الإحصائي SPSS والذي يشير

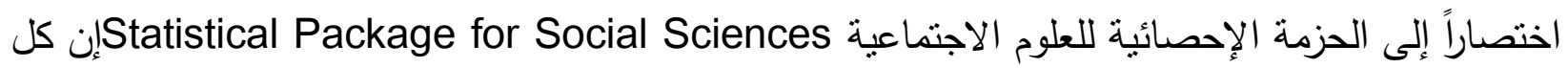

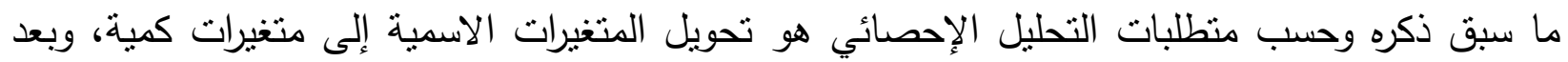
ذلك سيتم استخدام اختبار مربع كأي لمعرفة دلالة الفروق في إجابات أفراد الدراسة على عبارات فرضية الإبية الدراسة.

\section{خامساً: اختبار صحة فرضية الدراسة:}

للإجابة على تساؤلات الدراسة والتحقق من فرضيتها سيتم حساب الوسيط لكل عبارة من عبارات الاسنتيان والتي تبين أراء أفراد الدراسة، حيث تم إعطاء الدرجة (5) كوزن لكل إجابة "أوافق بشدة"، والدرجة

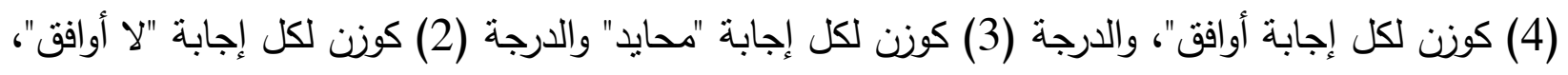
والدرجة (1) كوزن إجابة" لا أوافق بثدة"، ولمعرفة اتجاه الاستجابة فإنه يتم حساب الوسيط.

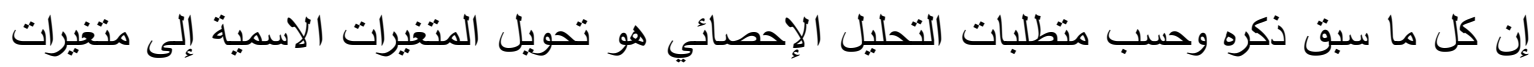

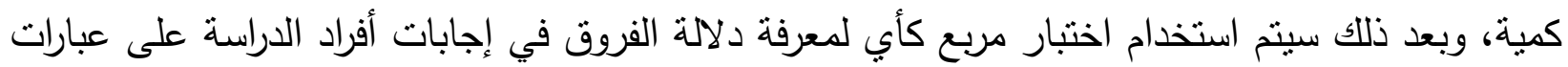
فرضية الدراسة. عبارات الاستبانة: الأسئلة المتعلقة بالدراسة: المحور الأول: (هل تخضع الأفلام الوثائقية التي تروج للسياحة في السودان للمعايير المهنية والفنية

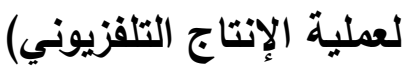

الجدول (5) التالي يبين التوزيع التكراري لإجابات أفراد الدراسة علي عبارات المحور الأول

\begin{tabular}{|c|c|c|c|c|c|c|}
\hline لا بشدة أوافق & لا ل أوافق & 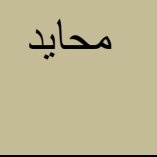 & 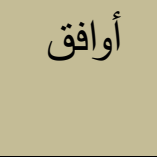 & بثدة أوافق & 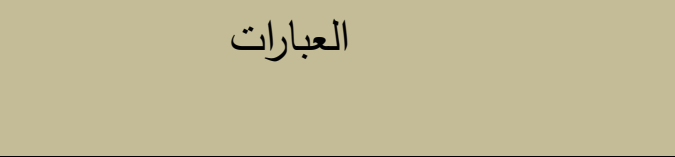 & 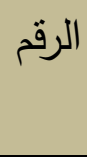 \\
\hline 0 & 5 & 3 & 12 & 3 & الفيلم الوثائق للسياحة في تطور مستمر في & 1 \\
\hline$\% 0.0$ & $\% 21.7$ & $\% 13.0$ & $\% 52.2$ & $\% 13.0$ & 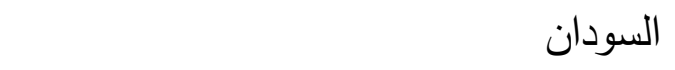 & \\
\hline 0 & 1 & 0 & 8 & 14 & الفيلم الوثائقي له دور واضح ومؤثر وفعال & 2 \\
\hline
\end{tabular}




\begin{tabular}{|c|c|c|c|c|c|c|}
\hline$\% 0.0$ & $\% 4.3$ & $\% 0.0$ & $\% 34.8$ & $\% 60.9$ & للترويج للسياحة & \\
\hline 1 & 6 & 4 & 9 & 3 & الأفلام الوثائقية التي تروج للسياحة في السودان & 3 \\
\hline$\% 4.3$ & $\% 26.1$ & $\% 17.4$ & $\% 39.1$ & $\% 13.0$ & تخضع للمعايير المهنية والفنية & \\
\hline
\end{tabular}

النتائج أعلاه لا تعنى أن جميع المبحوثين متفقون على ذللك، ولاختبار وجود فروق ذات دلالة إحصائية بين

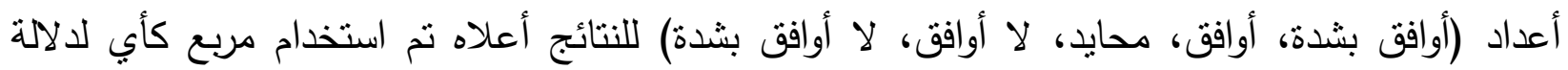

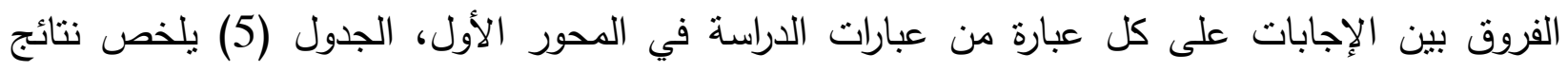
الاختبار لهذه العبارات: (هل تخضع الأفلام الوثائقية التي تروج للسياحة في السودان للمعايير المهنية والفنية لعملية الإنتاج التلفزيوني) المحور الثاني: (إلي أي مدي هنالك إنتاج أفلام وثائقية تروج للسياحة في السودان) الجدول الثالي بيين التوزيع التكراري لإجابات أفراد الدراسة علي عبارات المحور الثاني:

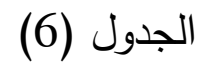

\begin{tabular}{|c|c|c|c|c|c|c|}
\hline لأبدة & لا أوافق & محايد & أوافق & 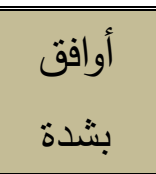 & العبارات & الرقم \\
\hline $\begin{array}{c}0 \\
\% 0.0\end{array}$ & $\begin{array}{c}3 \\
\% 13.0\end{array}$ & $\begin{array}{c}3 \\
\% 13.0\end{array}$ & $\begin{array}{c}15 \\
\% 65.2\end{array}$ & $\begin{array}{c}2 \\
\% 8.7\end{array}$ & يتم إنتاج أفلام وثائقية تروج للسياحة في & 1 \\
\hline $\begin{array}{c}1 \\
\% 4.3\end{array}$ & $\begin{array}{c}3 \\
\% 13.0\end{array}$ & $\begin{array}{c}1 \\
\% 4.3\end{array}$ & $\begin{array}{c}13 \\
\% 56.5\end{array}$ & $\begin{array}{c}5 \\
\% 21.7\end{array}$ & النتاج الأفلام الوثائقية المروجة للسياحة في & 2 \\
\hline $\begin{array}{c}1 \\
\% 4.3\end{array}$ & $\begin{array}{c}7 \\
\% 30.4\end{array}$ & $\begin{array}{c}7 \\
\% 30.4\end{array}$ & $\begin{array}{c}5 \\
\% 21.7\end{array}$ & $\begin{array}{c}3 \\
\% 13.0\end{array}$ & الفودان الوثائقي للسياحة في ازدياد مستمر في & 3 \\
\hline
\end{tabular}

النتائج أعلاه لا تعنى أن جميع المبحوثين متفقون على ذللك، ولاختبار وجود فروق ذات دلالة إحصائية بين

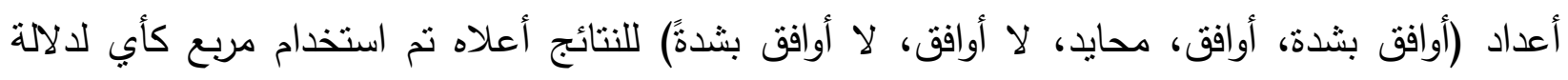

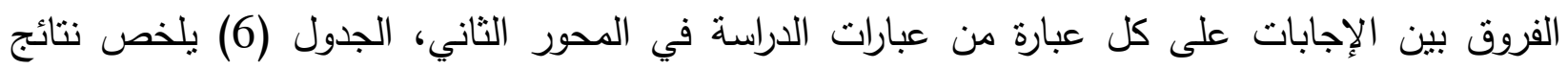
الاختبار لهذه العبارات:(إلى أي مدي هناللك إنتاج أفلام وثائقية تروج للسياحة في السودان) 
المحور الثالث: (ما الكيفية التي يمكن بها إنتاج أفلام وثائقية تروج للسياحة في السودان "مرتكزات نجاح

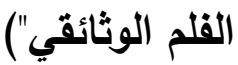
الجدول التالي يبين التوزيع التكراري لإجابات أفراد الدراسة علي عبارات المحور الثالث

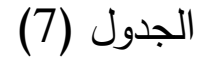

\begin{tabular}{|c|c|c|c|c|c|c|}
\hline لأبثدة & لا لا ل أوافق & 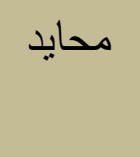 & أوافق أق & 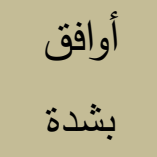 & العبارات & 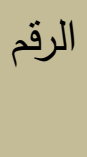 \\
\hline $\begin{array}{c}0 \\
\% 0.0\end{array}$ & $\begin{array}{c}1 \\
\% 4.3\end{array}$ & $\begin{array}{c}0 \\
\% 0.0\end{array}$ & $\begin{array}{c}11 \\
\% 47.8\end{array}$ & $\begin{array}{c}11 \\
\% 47.8\end{array}$ & مرتكزات نجاحه وأهمية الموضوع من أهم & 1 \\
\hline $\begin{array}{c}0 \\
\% 0.0\end{array}$ & $\begin{array}{c}1 \\
\% 4.3\end{array}$ & $\begin{array}{c}1 \\
\% 4.3\end{array}$ & $\begin{array}{c}6 \\
\% 26.1\end{array}$ & $\begin{array}{c}15 \\
\% 65.2\end{array}$ & جودة الصورة والصوت & 2 \\
\hline $\begin{array}{c}0 \\
\% 0.0\end{array}$ & $\begin{array}{c}1 \\
\% 4.3\end{array}$ & $\begin{array}{c}1 \\
\% 4.3\end{array}$ & $\begin{array}{c}6 \\
\% 26.1\end{array}$ & $\begin{array}{c}15 \\
\% 65.2\end{array}$ & توفير التقنيات الحديثة & 3 \\
\hline $\begin{array}{c}1 \\
\% 4.3\end{array}$ & $\begin{array}{c}0 \\
\% 0.0\end{array}$ & $\begin{array}{c}0 \\
\% 0.0\end{array}$ & $\begin{array}{c}3 \\
\% 13.0\end{array}$ & $\begin{array}{c}19 \\
\% 82.6\end{array}$ & توفير التمويل الكافي & 4 \\
\hline $\begin{array}{c}1 \\
\% 4.3\end{array}$ & $\begin{array}{c}0 \\
\% 0.0\end{array}$ & $\begin{array}{c}0 \\
\% 0.0\end{array}$ & $\begin{array}{c}7 \\
\% 30.4\end{array}$ & $\begin{array}{c}15 \\
\% 65.2\end{array}$ & الكادر المؤهل والمدرب & 5 \\
\hline $\begin{array}{c}1 \\
\% 4.3\end{array}$ & $\begin{array}{c}0 \\
\% 0.0\end{array}$ & $\begin{array}{c}1 \\
\% 4.3\end{array}$ & $\begin{array}{c}3 \\
\% 13.0\end{array}$ & $\begin{array}{c}18 \\
\% 78.3\end{array}$ & الروية الإخراجية المميزة & 6 \\
\hline
\end{tabular}

النتائج أعلاه لا تعنى أن جميع المبحوثين متفقون على ذللك، ولاختبار وجود فروق ذات دلالة إحصائية بين

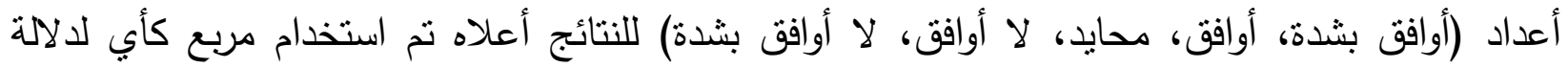
الفروق بين الإجابات على كل عبارة من عبارات الدراسة في المحور الثالث، الجدول (7) يلخص نتائج

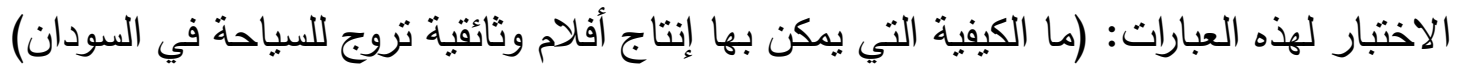


المحور الرابع: (إلي أي مدي ساهمت سلسلة أفلام أرض السمر في الترويج للسياحة في السودان)

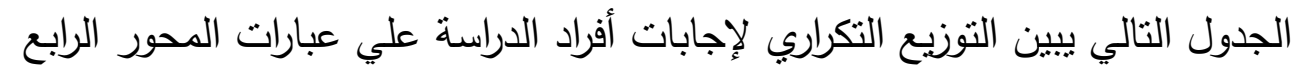

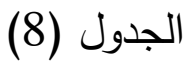

\begin{tabular}{|c|c|c|c|c|c|c|}
\hline لا بثدة أوافق & لا لا أوافق & 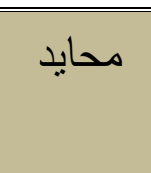 & 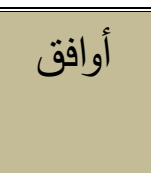 & بشدة & 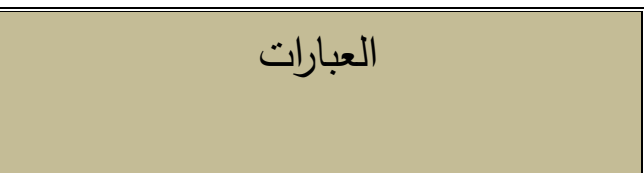 & 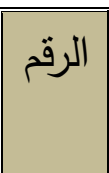 \\
\hline 1 & 1 & 2 & 13 & 6 & كانت ذات تأثنير إيجابي كبير علي & 1 \\
\hline$\% 4.3$ & $\% 4.3$ & $\% 8.7$ & $\% 56.5$ & $\% 26.1$ & الملنقي & \\
\hline 2 & 2 & 4 & 13 & 2 & موضوع وفكرة السلسلة كانت جيدة & 2 \\
\hline$\% 8.7$ & $\% 8.7$ & $\% 17.4$ & $\% 56.5$ & $\% 8.7$ & وخلاقة & \\
\hline 1 & 1 & 3 & 12 & 6 & جودة الصورة كانت عالية & 3 \\
\hline$\% 4.3$ & $\% 4.3$ & $\% 13.0$ & $\% 52.2$ & $\% 26.1$ & & \\
\hline 1 & 4 & 3 & 12 & 3 & ساهمت في التزريج للسياحة بصورة كبيرة & 4 \\
\hline$\% 4.3$ & $\% 17.4$ & $\% 13.0$ & $\% 52.2$ & $\% 13.0$ & & \\
\hline 2 & 1 & 7 & 10 & 3 & تم تطبيق كل المعايير المهنية والفنية في & 5 \\
\hline$\% 8.7$ & $\% 4.3$ & $\% 30.4$ & $\% 43.5$ & $\% 13.0$ & إنتاج هذه السلسلة & \\
\hline
\end{tabular}

النتائج أعلاه لا تعنى أن جميع المبحوثين متفقون على ذلك، ولاختبار وجود فروق ذات دلالة إحصائية بين

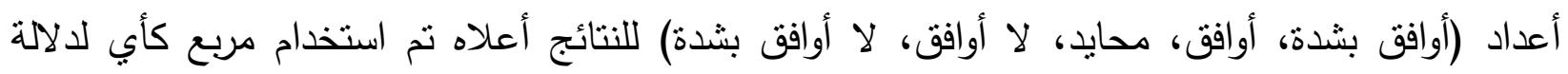

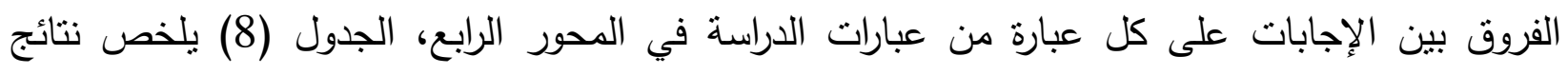
الاختبار لهذه العبارات: (إلي أي مدي ساهدت سلسلة أفلام أرض السمر في التزريج للسياحة في السودان) 
المحور الخامس: (التحديات التي تواجه إنتاج الأفلام الوثائقية التي تروج للسياحة في السودان)

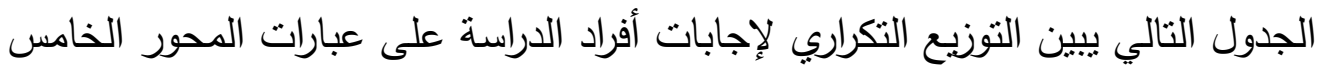

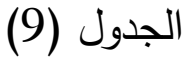

\begin{tabular}{|c|c|c|c|c|c|c|}
\hline لا لاوافق & لا أوافق & محايد & أوافق & 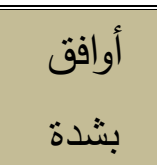 & العبارات & الرقم \\
\hline $\begin{array}{c}0 \\
\% 0.0\end{array}$ & $\begin{array}{c}0 \\
\% 0.0\end{array}$ & $\begin{array}{c}1 \\
\% 4.3\end{array}$ & $\begin{array}{c}4 \\
\% 17.4\end{array}$ & $\begin{array}{c}18 \\
\% 78.3\end{array}$ & ضعف التمويل & 1 \\
\hline $\begin{array}{c}0 \\
\% 0.0\end{array}$ & $\begin{array}{c}4 \\
\% 17.4\end{array}$ & $\begin{array}{c}1 \\
\% 4.3\end{array}$ & $\begin{array}{c}11 \\
\% 47.8\end{array}$ & $\begin{array}{c}7 \\
\% 30.4\end{array}$ & 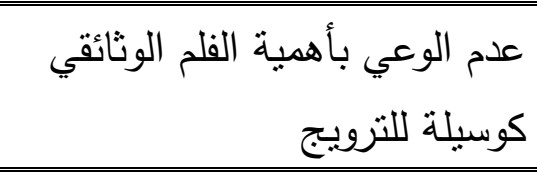 & 2 \\
\hline $\begin{array}{c}0 \\
\% 0.0\end{array}$ & $\begin{array}{c}1 \\
\% 4.3\end{array}$ & $\begin{array}{c}2 \\
\% 8.7\end{array}$ & $\begin{array}{c}14 \\
\% 60.9\end{array}$ & $\begin{array}{c}6 \\
\% 26.1\end{array}$ & الصباحة الصات والحروب وتأثيرها علي & 3 \\
\hline $\begin{array}{c}1 \\
\% 4.3\end{array}$ & $\begin{array}{c}10 \\
\% 43.5\end{array}$ & $\begin{array}{c}3 \\
\% 13.0\end{array}$ & $\begin{array}{c}8 \\
\% 34.8\end{array}$ & $\begin{array}{c}1 \\
\% 4.3\end{array}$ & قلة الكادر المؤهل والمدرب & 4 \\
\hline
\end{tabular}

النتائج أعلاه لا تعنى أن جميع المبحوثين متفقون على ذللك، ولاختبار وجود فروق ذات دلالة إحصائية بين أعداد (أوافق بشدة، أوافق، محايد، لا أوافق، لا أوافق بشدة) للنتائج أعلاه تم استخدام مربع كأبي لدلالة الفروق بين الإجابات على كل عبارة من عبارات الدراسة في الدحور الخام، الجدول (9) يلخص نتائج

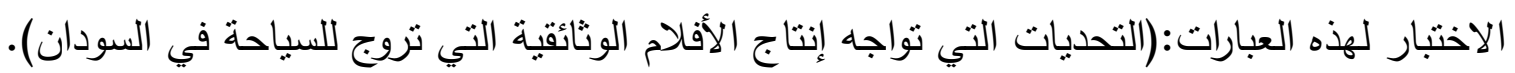

\section{تحليل مضمون}

1. السمة الغالبة لهذه السلسلة تتشكل من عرض الخلفيات التاريخية: والتقافية للمكان/ فضلا عن معلومات جغرافية عن المكان أيضاً، تم عرضها بشكل موجز ، وفي قالب فني. 2. اعتمدت السلسلة على البنيات التحنية منل الأهرامات وغيرها من المباني الأثرية والتاريخية، والمباني ذات الطبيعة الدينية كالخلاوى والأضرحة إلى جانب الكيفية التي يعيش بها الناس من أنماط الحياة المختلفة، وهذا برأيي كافي لرسم الصورة الحقيقية للإنسان في إي منطقة والثقافة التي توجه حياته في الجوانب الروحية والعادات والتقاليد التي بتوارثها. 
3. فكرة السلسلة كأفلام سياحية تعتبر جيدة جداً، لأنها عكست في السلسلة الأولى والثانية والثالثة ما تتمتع به البلاد من إمكانيات سياحية كبيرة، مراعية التتوع في العرض والتعليق الموجز .

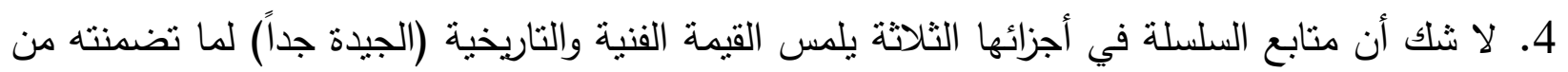

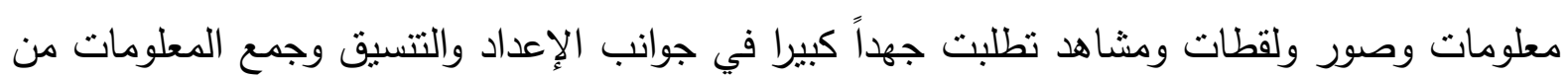
المصادر المختلقة. وهذه المضامين برأيي تمثل قاعدة بيانات للباحثين في التاريخ و "الاستثمار" السياحي. 5. النصوص والمعلومات جاء أغلبها على طريقة "الرواية" فضلاً عن المقابلات، وتمت الاستعانة بالخرائط التقليدية وخرائط "جوجل" والصور ثلاثية الأبعاد، والجرافيكس، والتقييم العام لمستوى المعالجة للنصوص منتاز . 6. من أصعب الأمور في المجال الإذاعي والتلفزيوني هو تقييم بعض الجوانب الفنية، رغم أن هناك قواعد مهنية حرفية يجب الالتزام بها، لكن عندما يكون للعمل الفني أهداف عديدة ومتاخلة (كهذه السلاسل) تصبح الخيارات الفنية أكثر اتناعاً والقيود أقل بالنسبة للمخرج، ونعتقد أن القيمة الفنية لهذه السلاسل

$$
\text { (المؤثرات الصوتية والبصرية وغيرها) جيدة جداً. }
$$

7. في بعض الأحيان تبدو الانتقالات من لقطة لأخرى غير مريحة، وغير منسقة، كالانتقال من لقطة ثابتة لأخرى استعراضية، وقريبة تعقبها أخرى بعيدة، وهذا ما ينسبب في تشويش بصري للمشاهد، لكن يمكن

$$
\text { القول إن مستوى المونتاج كان جيداً. }
$$

8. وأخيراً يمكن تقييم سلسلة أرض السمر بشكل عام من ناحية المعالجة الفنية والفنيات الإخراجية، بدايةً من شعار الحلقات من ناحية الصوت والعناوين، واستخدام الموسيقى كان بمستوى معتدل، أما من ناحية صياغة النص فهو بسيط معتمداً على معلومات صحيحة وممتازة ولغة سليمة وحبكة قصصية جيدة ولغة صورة جيدة مما ساعد على التعليق بوضوح في مخارج الحروف وسلامة الأداء، ومن الناحية البصرية كانت تكوين اللقطات جيد جداً بنسبة لحسن اختيار زوايا الكاميرا وحركتها وكفاءة الصورة والإضاءة داخل الفيلم وتتاسب المناظر الطبيعية وحسن استخدام المؤثرات الصوتية جميعهاً يرجع إلى أن المونتاج نجح وتميز بوضوح الصورة مع التعليق بتوافق ممتاز مع تزامن الصورة مع الصوت الطبيعي والتتابع وقلة تكرار اللقطات. 
ويمكن القول إن سلسلة أرض السمر كانت من الأفلام التي كان لها دور للتعريف بالسودان من حيث الأماكن السياحية والعادات والتقاليد والتراث، وكان هنالك اجتهاد واضح من قبل منتجي السلسلة من ناحية التقنية وظهر ذلك جلياً في طبيعة المشاهد التي تم تصويرها كمضامين لحلقات سلسلة أرض السمر . النتائج والتوصيات

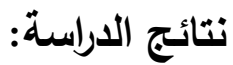

1. الأفلام الوثائقية التي تروج للسياحة في السودان تخضع لثيء من المعايير المهنية والفنية. 2. هناك ضعف في الأفلام الوثائقية التي تروج للسياحة في السودان.

3. وضحت الدراسـة أن أهم مرتكزات نجاح الفيلم الوثائقي هو تميز وأهمية الموضـوع بالإضـافة إلى لى

$$
\text { وجود الكادر المؤهل والمدرب. }
$$

4. كثفت الدراسة أن سلسلة أرض السمر ساهمت في الترويج للسياحة في السودان بصورة كبيرة.

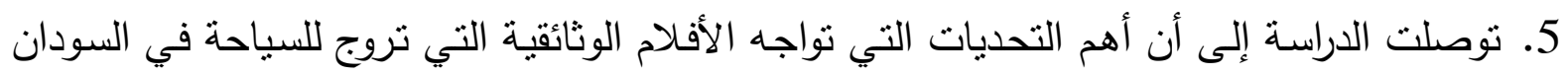
هي ضعف التمويل والصراعات والحروب وتأثيرها على السياحة. 6. بينت الدراسة أن للفلم الوثائقي دور واضح ومؤثر فعال للترويج للسياحة. توصيات الاراسة:

1. إجراء مزيد من البحوث في مجال تطوير صناعة الفيلم الوثائقي في السودان.

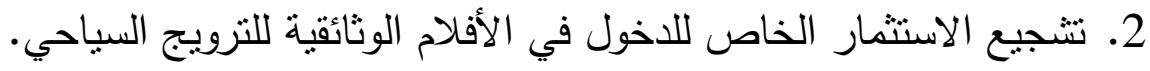
3. توفير التمويل الكافي لإعداد أفلام تستطيع لعب الدور المنوط بها وفق أهدافها.

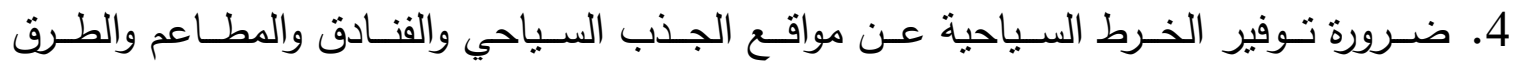
والمواصلات.

5. تخصيص فترات زمنية تلفزيونية داخل ذروة المشاهدة للأفلام الوثائقية بمختلف تخصصاتها.

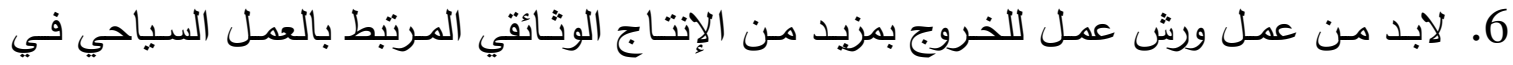

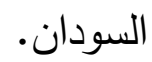




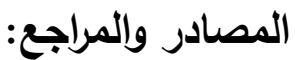

1. أحمد الجلاد، التتمية والإعلام السياحي المستدام، عالم الكتب للنشر والتوزيع، القاهر، غير شبه سنة النشر

2. الأرقم الجيلانسي، المـخل إلى صـناعة الأفـلام الوثائقيـة، شـركة مطـابع العملـة السودانية، الخرطوم، 2009

3. أيمن عبد الحليم نصار، إعداد البرامج الوثائقية، ط1، دار المنهج للنشر والتوزيع، الأردن، 2015م.

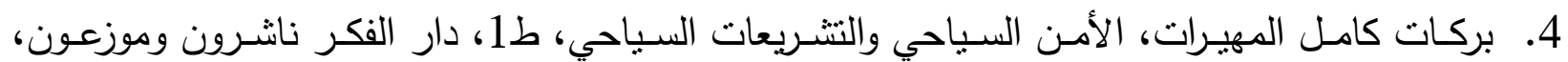
عمان، 2009م. 5. برير الرصيني محمد تيراب، دور البرامج الإذاعية في الترويج للسياحة في السودان، رسالة ماجستير

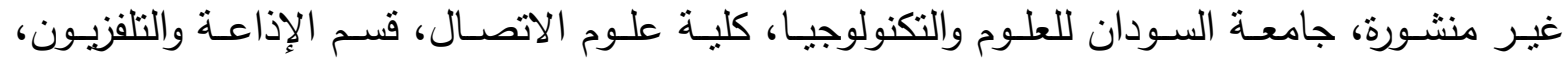
.2015

6. زيد منير سلمان، أساسيات نتظيم الرحلات السياحية، ط1، زمزم ناشرون وموزعون، الأردن، عمان، .2016

7. يد منير عبدي، مبادئ السياحة الحديثة، ط1، دار المفتي للنشر والتوزيع، الأردن، 2016م.

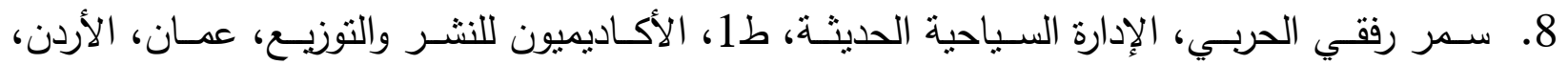
.2014

9. صفاء فوزي علي، الفيلم التسجيلي، دار الكتاب الحديث، القاهرة، 2015م. 10.فؤادة البكري، العلاقات العامة في المنشآت السياحية، ط1، عالم الكتاب للنشر والتوزيع، 2004م. 11. محمد الصيرفي، تتشيط المبيعات السياحية، ط1، دار السحاب للنشر والتوزيع، القاهرة، 2010م . 12. محمد قرافي، الصورة السينمائية والتعبير اللغوي، مجلة عالم الفكر، الهجلد (31)، 2002م. 13.محمد منير حجاب، الإعلام السياحي، ط2، دار الفجر للنشر والتوزيع، القاهرة، 2003م.

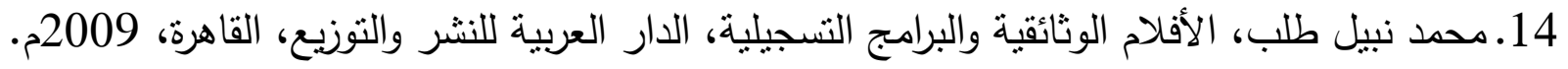
15.منى سعيد الحديد، سلوى إمام السينما التسجيلية، ط1، دار الفكر العربي، القاهرة، 2010م.

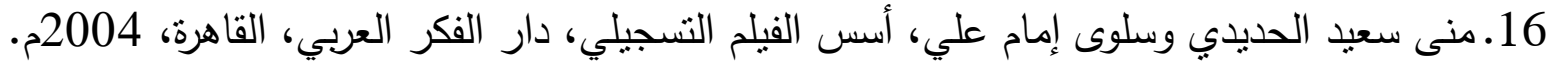
17. هبة عبد الرحيم منير ، الفيلم الوثائقي ودره في تعزيز السياحة في السودان، رسالة ماجستير غير منشورة، جامعة السودان للعلوم والتكنولوجيا، كلية علوم الاتصال، قسم الإذاعة والتلفزيون، 2015م. 18. هدى لطيف، السياحة مدخل وروئة، هيئة النيل العربية للنشر والتوزيع، القاهرة، غير مبينة سنة النشر . 
19. يسـرى ولمسيس، السـياحة مفهومهـا وأنماطهـا، ط1، الملتقى المصـري للإبـداع والتتميـة، الإسـكندرية، 2001 